\title{
Uji Antibakteri Obat Kumur Ekstrak Etanol Tanaman Ciplukan (Physalis angulata 1.) Terhadap Bakteri Gram Positif
}

\author{
R. Teti Rostikawati ${ }^{1)}$ dan Lilis Supratman ${ }^{2)}$ \\ Email: ${ }^{1}$ rostikawati@unpak.ac.id \\ ${ }^{2}$ lilissupratman84@gmail.com
}

\author{
APA Citation: $\quad$ Rostikawati, R. Teti., Supratman, Lilis. Uji Antibakteri Obat Kumur Ekstrak \\ Etanol Tanaman Ciplukan (Physalis Angulata L) terhadap Bakteri Gram \\ Positif. Quagga: Jurnal Pendidikan dan Biologi, 13(1), 103-107. doi: \\ 10.25134/quagga.v13i1.3827.
}

Received: $14-12-2020$

Accepted: $30-12-2020$

Published: 01-01-2021

Abstrak: Mulut memiliki mikrofloranormal bakteri sebagai pertahanan tubuh. Bakteri Streptococcus mutans merupakan bakteri yang berkelompok pada permukaan gigi yang memiliki peranan dalam pembentukan karies gigi. Daun dan batang Ciplukan (Physalis angulata L.) mengandung polifenol, flavonoid, dan etanol serta antioksidan yang kuat yang diduga memiliki aktivitas antimikroba yang sangat baik. Tujuan penelitian ini yatu untuk mengetahui daya antibakteri obat kumur ekstraksisi etanol campuran daun dan batang ciplukan (P. angulata L.) terhadap bakteri Streptococcus mutans. Metode penelitian bersifat eksperimental murni laboratorium yang menggunakan kulturisasi bakteri S. mutans. Uji daya antibakteri menggunakan cara dengan dilusi cair dan dilanjutkan dengan dilusi padat. Uji analisis statistik menggunakan uji deskriptif. Dari hasil penelitian menunjukkan bahwa pada konsentrasi 15\% obat kumur ekstraksi etanol campuran daun dan batang ciplukan mempunyai kadar hambat minimal (KHM) dan kadar bunuh minimal (KBM). Formulasi ini bisa direkomendasikan untuk dilakukan penelitian lebih lanjut agar bisa digunakan oleh masyarakat yang tinggal dikawasan suhu dingin.

Kata Kunci: Ciplukan, obat kumur, Streptoccus mutans.

\begin{abstract}
Abstrak: The mouth has microfloranormal bacteria as a defense of the body. Mutant Streptococcus bacteria are bacteria that cluster on the surface of the teeth that have a role in the formation of dental caries. Ciplukan leaves and stems (Physalis angulata L.) contain polyphenols, flavonoids, and ethanol as well as powerful antioxidants that are thought to have excellent antimicrobial activity. The purpose of this study was to find out the antibacterial power of ethanol extraction drugs mixed with leaves and stems ciplukan (P. angulata L.) against bacteria Streptococcus mutants. The research method is purely experimental laboratory that uses the culture of bacteria S. mutants. Antibacterial power test using a means with liquid dilution and continued with solid dilution. Test statistical analysis using descriptive tests. From the results of the study showed that at a concentration of $15 \%$ mouthwash ethanol extraction mixed leaves and stems ciplukan have minimal levels of bland (KHM) and minimal kill rate (KBM). This formulation can be recommended for further research so that it can be used by people living in cold temperatures.
\end{abstract}

Keywords: Ciplukan, mouthwash, Streptoccus mutants

\section{PENDAHULUAN}

Karies gigi yaitu penyakit gigi yang melibatkan email, dentin dan semen. Penyakit karies disebabkan oleh aktivitas mikroba pada sisa-sisa makanan yang difermentasi dengan ditandai oleh proses demineralisasi jaringan gigi (Kidd, 1992). Berdasarkan klasifikasi bakteri streptococcus, Streptococcus mutans merupakan kelompok dari bakteri $S$. viridans.

Streptococcus mutans berkelompok pada permukaan gigi khususnya supragingiva dan merupakan bakteri yang kompleks kurang lebih ada 700 spesies (Biswas, 2012). Penggunaan obat kumur merupakan salah satu cara untuk menjaga kebersihan mulut dan banyak diminati di negara berkembang. Secara umum obat kumur herbal tidak mengandung gula dan alkohol, dua bahan tersebut adalah bahan baku untuk mikroba yang sangat mudah difermentasi. Physali angulate $L$. merupakan jenis tanaman tahunan yang dapat ditemukan di daerah tropis di berbagai belahan dunia.

Physalis angulate L. banyak ditemukan di daerah-daerah tropis diantaranya Afrika, Asia, dan Amerika. Tanaman ciplukan ( $P$. angulata $L)$ bisa tumbuh mencapai 1 meter dengan morfologi batang kecil, warna bunga krem dan buah berwarna oranye kekuningan. Berdasarkan hasil penelitian fitokimia dilaporkan bahwa akar dan batang tanaman ciplukan banyak mengandung 
saponin dan flavonoid (AS, 2014). Daun ciplukan banyak mengandung polifenol, flavonoid, dan alkaloid. senyawa aktif tersebut diduga memiliki aktivitas antimikroba yang cukup baik (Fitrianti,2011). Susanti (2013) menyebutkan batang ciplukan memiliki aktifitas antioksidan yang kuat, selain itu kadar fenol dan flavonoid yang mampu mendegradasi peptidoglikan bakteri secara efektif. Berdasarkan latar belakang diatas maka penting dilakukan penelitian mengenai efektifitas daya antibakteri obat kumur ekstraksi etanol campuran daun dan batang ciplukan untuk mengetahui daya antibakteri dari senyawa aktif yang terkandung dalam campuran daun dan batang ciplukan terhadap bakteri S. mutans yang merupakan penyebab karies gigi.

\section{METODOLOGI PENELITIAN}

Penelitian ini adalah penelitian eksperimental murni laboratorium yang dilakukan secara in vitro. Terdapat 5 kelompok konsentrasi obat kumur ekstraksi etanol campuran daun dan batang ciplukan (P. angulata $L$.) yaitu $5 \%, 10 \%$, $15 \%, 20 \%$, dan $25 \%$ serta kelompok kontrol positif yaitu formula dasar obat herbal kumur dan kelompok kontrol negatif yaitu Chlorhexidine gluconate $0,2 \%$

Isolasi bakteri $S$. mutans dilakukan dengan cara disubkulturisasi pada lempeng media Tryptic Soy Agar (TSA) selama 18-24 jam pada suhu $28^{\circ} \mathrm{C}$. Kemudian dengan menggunakan ose steril beberapa koloni bakteri diseleksi dan diinokulasi ke dalam larutan $\mathrm{NaCl}$ sebanyak 1-2 ml. Lalu diinkubasi selama 2-4 jam pada suhu $28^{\circ} \mathrm{C}$. Setelah itu dilankukan pengenceran dengan menambah larutan BHI (Brain Heart Infusion) sehingga didapatkan jumlah bakteri yang sesuai dengan larutan Standart Brown III yang diidentifikasikan yang setara dengan konsentrasi bakteri sebesar $10^{8} \mathrm{CFU} / \mathrm{ml}$. Kemudian bakteri S. mutans dilakukan pengenceran lagi dengan melibatkan media cair BHI sehingga konsentrasi media bakteri menjadi $10^{6} \mathrm{CFU} / \mathrm{ml}$.

Tabel 1. Komposisi Obat Kumur EkstrakEtanol Daun Ciplukan (Physalis angulata L)

\begin{tabular}{|l|c|c|c|c|c|}
\hline \multirow{2}{*}{ Bahan } & $\begin{array}{c}\text { Formula } \\
\text { I }\end{array}$ & $\begin{array}{c}\text { Formula } \\
\text { II }\end{array}$ & $\begin{array}{c}\text { Formula } \\
\text { III }\end{array}$ & $\begin{array}{c}\text { Formula } \\
\text { IV }\end{array}$ & $\begin{array}{c}\text { Formula } \\
\text { V }\end{array}$ \\
\cline { 2 - 6 } & $\mathbf{5 \%}$ & $\mathbf{1 0 \%}$ & $\mathbf{1 5 \%}$ & $\mathbf{2 0 \%}$ & $\mathbf{2 5 \%}$ \\
\hline Ekstrak Etanol & 2.5 & 5 & 7.5 & 10 & 12.5 \\
\hline Peppermint oil (ml) & 0.5 & 0.5 & 0.5 & 0.5 & 0.5 \\
\hline Na-Sakarin (gr) & 0.3 & 0.3 & 0.3 & 0.3 & 0.3 \\
\hline Asam Benzoat (gr) & 0.025 & 0.025 & 0.025 & 0.025 & 0.025 \\
\hline Aquades ad (ml) & 50 & 50 & 50 & 50 & 50 \\
\hline Volume Akhir (ml) & 50 & 50 & 50 & 50 & 50 \\
\hline
\end{tabular}

Campuran antara daun dan batang ciplukan $(P$. angulata $L$.) yang telah diekstraksi di laboratorium dibagi dalam bentuk 5 formula menjadi obat kumur yang disajikan pada Tabel. 1 . Uji daya antibakteri ekstraksi campuran daun dan batang ciplukan $(P$. angulata $L$.) menggunakan metode pengenceran tabung (tube dilution method).

Disediakan 28 tabung steril dengan melakukan 4 kali pengulangan, setiap pengenceran tiap satu ulangan melibatkan 5 tabung dan 2 tabung digunakan sebagai sisa pengenceran, kontrol pertumbuhan bakteri (kontrol positif) dan kontrol media (kontrol negatif). Pengenceran pertama bertujuan untuk menguji kadar hambat minimal dan kadar bunuh minimal dari daun ciplukan. Persiapan tabung uji sebanyak 7 tabung.

a. Tabung I diisi $1 \mathrm{ml}$ formula $1+1 \mathrm{ml}$ suspensi bakteri $10^{6} \mathrm{CFU} / \mathrm{ml}$.

b. Tabung II diisi $1 \mathrm{ml}$ formula $2+1 \mathrm{ml}$ suspensi bakteri $10^{6} \mathrm{CFU} / \mathrm{ml}$.

c. Tabung III diisi $1 \mathrm{ml}$ formula $3+1 \mathrm{ml}$ suspensi bakteri $10^{6} \mathrm{CFU} / \mathrm{ml}$.

d. Tabung IV diisi $1 \mathrm{ml}$ formula $4+1 \mathrm{ml}$ suspensi bakteri $10^{6} \mathrm{CFU} / \mathrm{ml}$.

e. Tabung $\mathrm{V}$ diisi $1 \mathrm{ml}$ formula $5+1 \mathrm{ml}$ suspensi bakteri $10^{6} \mathrm{CFU} / \mathrm{ml}$.

f. Tabung VI diisi $1 \mathrm{ml}$ Chlorhexidine gluconate $0,2 \%+1 \mathrm{ml}$ suspensi bakteri (kontrol -)

g. Tabung VII diisi $1 \mathrm{ml}$ formula dasar obat kumur ekstrak etanol daun ciplukan konsentrasi $0 \%+1 \mathrm{ml}$ suspensi bakteri $10^{6}$ $\mathrm{CFU} / \mathrm{ml}$ (kontrol + ).

Kemudian seluruh tabung diinkubasikan pada suhu $28^{\circ} \mathrm{C}$ selama $18-24$ jam. Langkah selanjutnya yatu melakukan pengamatan secara deskriptif terhadap pertumbuhan bakteri dengan cara membandingkan tingkat kekeruhan larutan dengan tabung kontrol positif.

Kadar hambat minimal didapatkan dengan cara mengamati tabung yang tidak memperlihatkan adanya pertumbuhan bakteri pada konsentrasi terendah. Pada tabung subkultur yang tidak memperlihatkan pertumbuhan bakteri selanjutnya diinokulasi dengan menggunakan ose pada media Tryptic Soy Agar (TSA) yang diinkubasi pada suhu $28^{\circ} \mathrm{C}$ selama $18-24$ jam. Kadar bunuh minimal ditunjukan dengan tidak terlihatnya pertumbuhan bakteri pada medium agar nutrien dengan konsentrasi terendah.

Pembacaan KHM ditentukan dengan melihat kekeruhan pada cairan di dalam tabung 
reaksi yang dibandingkan dengan kontrol standar. Pembacaan nilai didasarkan pada:

a. Tanda negatif (-): dengan melihat adanya kejernihan pada tabung menunjukan tidak adanya pertumbuhan bakteri Streptococcus mutans sehingga obat kumur ekstrak daun ciplukan dapat menghambat pertumbuhan bakteri.

b. Tanda positif (+): dengan melihat adanya kekeruhan pada tabung menunjukan adanya pertumbuhan bakteri Streptococcus mutans sehingga obat kumur ekstrak daun ciplukan tidak dapat menghambat pertumbuhan bakteri.

Pembacaan KBM dapat ditentukan dengan menguji konsentrasi terkecil dari bahan uji yang diduga masih bisa membunuh bakteri. Hal diperkuat dengan pengamatan ada tidaknya pertumbuhan koloni bakteri $S$. mutans pada media TSA.

Berdasarkan data hasil penelitian, kemudian dilakukan analisis deskriptif dalam bentuk tabel hasil penelitan. Hasil penelitian dilakukan pembahasan dengan melihat KHM dan KBM daya antibakteri obat kumur ekstraksi etanol campuran daun dan batang ciplukan $(P$. angulata $L$.) terhadap bakteri S. mutans

\section{HASIL DAN PEMBAHASAN}

Tabel 2. Hasil pengujian dilusi cair ekstrak daun ciplukan (Physalis angulata L.) dalam bentuk sediaan obat kumur terhadap bakteri

\begin{tabular}{|c|l|c|c|c|c|}
\multicolumn{7}{c|}{ Streptococcus mutans } \\
\hline Tabung ke- & Bahan Uji & I & II & III & IV \\
\hline $\mathbf{l}$ & Formula I & - & - & - & - \\
\hline $\mathbf{2}$ & Formula II & - & - & - & - \\
\hline $\mathbf{3}$ & Formula III & - & - & - & - \\
\hline $\mathbf{4}$ & Formula IV & - & - & - & - \\
\hline $\mathbf{5}$ & Formula V & TT & TT & TT & TT \\
\hline $\mathbf{6}$ & $\begin{array}{l}\text { Kontrol } \\
\text { negative }\end{array}$ & - & - & - & - \\
\hline $\mathbf{7}$ & Kontrol positif & + & + & + & + \\
\hline
\end{tabular}

Hasil uji cair obat kumur herbal ekstraksi etanol campuran daun dan batang ciplukan $(P$. angulata L.) (Tabel 2) pada konsentrasi 15\% memperlihatkan tidak nampak pertumbuhan bakteri karena formula terlihat jernih, hal ini menunjukkan KHM perlu dilakukan inokulasi pada media padat. Pada konsentrasi 25\% tidak bisa dilakukan pengamatan karena terlalu pekat.
Tabel 3. Hasil deskriptif uji dilusi cair

\begin{tabular}{|c|c|c|c|c|c|}
\hline $\begin{array}{c}\text { Komponen } \\
\text { Pengamatan }\end{array}$ & Formula I & Formula II & $\begin{array}{c}\text { Formula } \\
\text { III }\end{array}$ & Formula IV & Formula V \\
\cline { 2 - 6 } & $5 \%$ & $10 \%$ & $15 \%$ & $20 \%$ & $25 \%$ \\
\hline $\begin{array}{c}\text { Warna larutan } \\
\text { sebelum } \\
\text { inkubasi }\end{array}$ & Bening & bening & bening & bening & bening \\
$\begin{array}{c}\text { Warna } \\
\text { larutansetelah } \\
\text { inkubasi }\end{array}$ & Bening & bening & bening & bening & bening \\
\hline $\begin{array}{c}\text { Aroma } \\
\text { Ada/tidaknya } \\
\text { endapan }\end{array}$ & peppermint & peppermint & peppermint & peppermint & peppermint \\
\hline $\begin{array}{c}\text { Warna endapan } \\
\text { Ada/tidaknya } \\
\text { gelembung gas }\end{array}$ & Tidak ada & Tidak ada & Tidak ada ada & Tidak ada & Ada \\
\hline
\end{tabular}

Hasil deskriptif uji dilusi cair / Penelitian ini dilakukan untuk mengetahui pengaruh uji ekstraksi campuran daun dan batang ciplukan $(P$. angulata $L$.) dalam bentuk obat kumur herbal terhadap bakteri S. mutans in vitro dengan metode dilusi cair dan dilanjutkan pengamatan dengan uji inokulasi pada media TSA untuk menentukan KHM dan KBM. Penelitian ini menggunakan suhu $28^{\circ} \mathrm{C}$, suhu ini berkaitan dengan suhu pada organ mulut manusia yang berada didataran tinggi atau pegunungan yang suhunya mencapai $5^{\circ} \mathrm{C}$. Hasil penelitian memperlihatkan tingkat konsentrasi 15\%. Tabel 3cukup efektif dalam formulasi. Diduga formula ini cocok untuk mereduksi bakteri yang bisa hidup optimum disuhu $20^{\circ}-40^{\circ} \mathrm{C}$.

Sunatmo (2009) menyatakan bahwa kelompok bakteri ini sering dikenal dengan kelompok bakteri psikrotoleran. Bakteri ini banyak dijumpai pada lingkungan dingin dengan suhu konstan dan akan segera mati jika pada suhu ruang sehingga dapat dilakukan bila akan menelaah, mentranspor, mengisolasi dan memberi perlakuan lain. Hal ini dikarenakan bakteri ini lebih senang pada suhu dingin konstan dibandingkan suhu dingin sekali. Formulasi obat kumur dengan konsentrasi $15 \%$ diduga bisa meminimalisir jumlah bakteri merugikan dalam rongga mulut yang mendiami kawasan dingin sehingga bisa direkomendasikan untuk dilakukan penelitian lebih lanjut dengan bakteri endemik lain yang berada dalam rongga mulut.

Berdasarkan hasil pengamatan menunjukkan bahwa ekstraksi daun dan batang ciplukan ( $P$. angulata $L$.) dalam bentuk obat kumur herbal memiliki pengaruh daya antibakteri terhadap bakteri $S$. mutans. Kadar hambat minimal adalah konsentrasi terendah yang 
memperlihatkan tidak adanya laju pertumbuhan bakteri yang bisa menghambat pertumbuhan bakteri dan bisa dilakukan pengamatan berdasarkan tingkat kekeruhan formula pada tiap tabung. Kadar bunuh minimal adalah konsentrasi terendah yang dapat menekan laju pertumbuhan bakteri dan dapat diamati berdasarkan tidak adanya kelompok bakteri pada media.

Kadar hambat minimal diamati dengan menggunakan metode dilusi cair yang dapat ditentukan berdasarkan tingkat kekeruhan tabung dimana pada tingkat konsentrasi $15 \%$ memperlihatkan kejernihan pada tabung yang artinya tidak terdapat pertumbuhan bakteri, setelah itu kemudian dilakukan inokulasi bakteri pada media agar dan diinkubasi selama 18-24 jam. Pada hasil pengamatan dilusi padat pada tingkat konsentrasi $15 \%$ memperlihatkan tidak adanya pertumbuhan bakteri pada media sehingga KHM terdapat pada tingkat konsentrasi di bawah $15 \%$.

Pada pengamatan hasil uji dilusi padat menunjukkan bahwa konsentrasi $15 \%$ merupakan KBM.

Uji dilusi padat merupakan uji yang dilakukan pada media untuk menentukan KBM dan memperkuat hasil dari uji dilusi cair. Kadar bunuh minimal terhadap bakteri $S$. mutans pada tingkat konsentrasi $15 \%$ didapatkan dengan cara mengamati laju pertumbuhan bakteri hasil dilusi cair yang diinokulasi pada media dengan ditandai dengan tidak ditemukannya pertumbuhan bakteri S. mutans pada media.

Salah satu bakteri utama penyebab karies gigi adalah S. mutans dimana bakteri ini memproduksi enzim glucosyltransferase (GTF), yang dapat membentuk koloni yang melekat dengan erat pada permukaan gigi.

Sesuai dengan pendapat Arezoo (2010) bahwa Streptococcus dapat menyebabkan plak gigi dan lebih jauh lagi dapat mengakibatkan karies gigi. $S$. mutans dapat menghasilkan polisakarida ekstraseluler yang lengket dari sisa makanan dan mampu memfermentasi karbohidrat menjadi zat asam (Biswas, 2012).

Dinding sel pada bakteri berfungsi melindungi struktur membran sitoplasma, memelihara bentuk sel bakteri, dan mencegah lisis karena adanya tekanan osmosis. Akibatnya dinding sel bakteri akan rusak atau tidak terbentuk maka sel akan lisis bahkan tidak dapat membelah.

Lisisnya sel terjadi karena pengaruh cairan disekitar yang bersifat hipoosmosis berdifusi ke dalam sel bakteri menyebabkan pembengkakan (swell) dan diikuti lisis. Selain menghasilkan polisakarida, bakteri endemik ini juga dapat memproduksi zat asam, zat asam yang terbentuk dapat merusak gigi karena dapat digunakan oleh bakteri lain sebagai sumber energi untuk melakukan demineralisasi permukaan email gigi (Aneja, 2010).

Flavonoid yang terkandung di dalam ekstraksi etanol campuran daun dan batang ciplukan memiliki kemampuan untuk membentuk kompleks protein ekstraseluler dan terlarut, dengan dinding sel, serta memiliki sifat lipofilik. Proses tersebut menyebabkan kerusakan membran sitoplasma sehingga sel bakteri akan rusak dan mati, juga membran sel akan rusak (Nanumala, 2012).

Alkaloid merupakan suatu senyawa hasil akhir dari reaksi detoksifikasi yang merupakan hasil metabolit akhir dari komponen yang membahayakan bagi tanaman Alkaloid memiliki fungsi sebagai zat antibakteri dengan cara mengganggu kestabilan komponen penyusun peptidoglikan pada dinding sel bakteri, sehingga lapisan dinding sel tidak terbentuk secara utuh dan menyebabkan kematian bakteri (Rifdayani, 2014).

Perbedaan tingkat sensitifitas dinding sel bakteri terhadap zat antibakteri sangat dipengaruhi oleh struktur dinding sel bakteri gram positif lebih sederhana dibandingkan struktur dinding sel bakteri gram negatif sehingga memudahkan zat antibakteri untuk berdifusi ke dalam sel bakteri gram positif (Priyanto, 2010).

Dinding sel bakteri gram positif mengandung (asam teikoat). Asam teikoat merupakan struktur polimer yang dapat larut dalam air dan berfungsi sebagai transportasi ion positif. Sifat larut inilah yang menunjukkan bahwa dinding sel pada bakteri gram positif bersifat polar. Flavonoid yang bersifat polar lebih mudah menembus peptidoglikan yang bersifat polar dibandngkan lapisan lipid yang bersifat nonpolar, sehingga menyebabkan tingkat aktivitas penghambatan pada tipe bakteri gram positif lebih besar daripada gram negatif.

Mekanisme kerja flavonoid sebagai bakterisidal terhadap laju pertumbuhan S. mutans yaitu dapat mengganggu fungsi struktur dinding sel sebagai pelindung dari lisis osmotik sehingga dapat berakibat pada kematian bakteri. Hal ini sesuai dengan pendapat Jawetz (2008) yang salah satu pendapatnya menyatakan bahwa flavonoid 
sebagai zat antibakteri yang dapat menghambat proses sintesis protein dan asam nukleat bakteri, dengan cara senyawa antibakteri merusak asamasam nukleat dan mendenaturasi protein sehingga menyebabkan gangguan proses sintesa protein dan asam nukleat, mengakibatkan kerusakan pada sel secara total.

Mekanisme kerja polifenol pada mikroorganisme sebagai inhibitor enzim oleh senyawa yang teroksidasi, kemungkinan melalui reaksi dengan grup sufhidril atau melalui interaksi non-spesifik dengan protein. Inhibitor enzim tersebut akan mengganggu fungsi enzim dan substratnya. Apabila fungsi dari enzim dan substrat terganggu maka lambat laun bisa mengakibatkan kematian sel. Fenol mampu berikatan dengan protein dengan melibatkan ikatan hidrogen sehingga mengakibatkan struktur protein mengalami kerusakan. Dikarenakan sebagian dari struktur dinding sel dan membran sitoplasma banyak mengandung protein dan lemak, maka zat fenol diduga dapat melakukan proses denaturasi protein dan membran sel pada bakteri. Fungsi permeabilitas selektif, fungsi pengangkutan aktif, pengendalian susunan protein dari sel bakteri menjadi terganggu diakibatkan oleh ketidakstabilan pada dinding sel dan membran sitoplasma bakteri.

\section{SIMPULAN}

Berdasarkan penelitian yang telah dilakukan dapat diambil kesimpulan bahwa pengaruh daya antibakteri obat kumur ekstrak etanol campuran daun dan batang ciplukan (Physalis angulata L.) dengan menggunakan metode maserasi telah terbukti teruji secara in vitro pada konsentrasi $15 \%$ memiliki pengaruh daya antibakteri terhadap bakteri $S$. mutans

\section{REFERENSI}

Aneja, K. R., Joshi, R., \& Sharman, C. 2010. The antimicrobial potential of ten often used mouthwashes against four dental caries patoghens. Jundishapur: Journal of Microbiology. 3(1): 15-27.

Arezoo, T., Rooha, K. K., Rasoul, S., Nafiseh, G. P. 2010. Biofilm formation potential of oral streptococci in related to some carbohydrate subtates. African Journal of Microbiology Research. 4(11): 1051-1058.

AS, Noorhamdani., Rio, J. A., \& Gracia, H. 2014. Uji Efektivitas Ekstrak Etanol Daun Ciplukan (Physalis angulata L.) terhadap Antimikroba Acinotebacter baumannii secara In Vitro. Majalah Gracia Harahap. Jurnal Penelitian Fakultas Kedokteran Universitas Brawijaya.

Biswas, S., \& Biswas, I. 2012. Complete genome sequence of Streptococcus mutans GS-5, a Serotype c Strain. Journal of Bacteriology. 194(17): 4787-4788.

Fitrianti, D., AS, N., \& Karyono, S, S. 2011. Efektivitas Ekstrak Daun Ceplukan sebagai Antimikroba terhadap MethicillinResistant. Jurnal Kedokteran Brawijaya. 26(4): 212-215.

Jawetz, Melnick, \& Adelberg. 2008. Mikrobiologi kedokteran. 23th ed. Jakarta: EGC.

Kidd, E. A., \& Bechal, S. J. 1992. DASAR-DASAR KARIES Penyakit dan Penanggulangannya. Edisi ke-2. Jakarta: EGC.

Nanumala, S. K., R, K., Gunda, K., G, S., \& P, S. 2012. Antiulcer activity of the ethanolic extract of leaves Physalis angulata L. International Journal of Pharmacy and Pharmaceutical Sciences. 4(4): 226-228.

Priyanto. 2010. Farmakologi Dasar. Edisi ke-2. Depok: LESKONFI.

Rifdayani, N., Budiarti, L. Y., \& Carabelly, A. N. 2014. Perbandingan Efek Bakterisidal Ekstrak Mengkudu (Morinda Citrifolia) $100 \%$ dan Povidone Iodine 1\% terhadap Streptococcus mutans In Vitro. Dentino Jurnal Kedokteran Gigi. 2(1): 1-6.

Sunatmo, TI. 2009. Mikrobiologi essensial 1. Jakarta:Ardy Agency. 